\title{
Factors affecting the adoption of activity-based costing at technical and vocational education and training colleges in KwaZulu-Natal, South Africa
}

\begin{tabular}{|c|c|}
\hline \multicolumn{2}{|c|}{$\begin{array}{l}\text { Authors: } \\
\text { Mziwendoda C. Madwe }{ }^{1} \text { (D) } \\
\text { Lesley J. Stainbank }{ }^{2} \text { (D) } \\
\text { Paul Green }{ }^{3}\end{array}$} \\
\hline \multicolumn{2}{|c|}{$\begin{array}{l}\text { Affiliations: } \\
{ }^{1} \text { Department of Accounting } \\
\text { and Auditing, University of } \\
\text { Zululand, Empangeni, } \\
\text { South Africa }\end{array}$} \\
\hline \multicolumn{2}{|c|}{$\begin{array}{l}{ }^{2} \text { Faculty of Accounting } \\
\text { and Informatics, Durban } \\
\text { University of Technology, } \\
\text { Durban, South Africa }\end{array}$} \\
\hline \multicolumn{2}{|c|}{$\begin{array}{l}{ }^{3} \text { Faculty of Business and } \\
\text { Management Sciences, } \\
\text { Cape Peninsula University } \\
\text { of Technology, Cape Town, } \\
\text { South Africa }\end{array}$} \\
\hline \multicolumn{2}{|c|}{$\begin{array}{l}\text { Corresponding author: } \\
\text { Mziwendoda Madwe, } \\
\text { madwem@unizulu.ac.za }\end{array}$} \\
\hline \multicolumn{2}{|c|}{$\begin{array}{l}\text { Dates: } \\
\text { Received: } 20 \text { Mar. } 2019 \\
\text { Accepted: } 24 \text { Jan. } 2020 \\
\text { Published: } 30 \text { June } 2020\end{array}$} \\
\hline \multicolumn{2}{|c|}{$\begin{array}{l}\text { How to cite this article: } \\
\text { Madwe, M.C., Stainbank, L.J. } \\
\text { \& Green, P., 2020, 'Factors } \\
\text { affecting the adoption of } \\
\text { activity-based costing at } \\
\text { technical and vocational } \\
\text { education and training } \\
\text { colleges in KwaZulu-Natal, } \\
\text { South Africa', Journal of } \\
\text { Economic and Financial } \\
\text { Sciences } 13(1) \text {, a467. } \\
\text { https://doi.org/10.4102/jef. } \\
\text { v13i1.467 }\end{array}$} \\
\hline \multicolumn{2}{|c|}{$\begin{array}{l}\text { Copyright: } \\
\text { (C) 2020. The Authors. } \\
\text { Licensee: AOSIS. This work } \\
\text { is licensed under the } \\
\text { Creative Commons } \\
\text { Attribution License. }\end{array}$} \\
\hline Read online: & \\
\hline 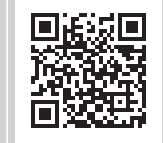 & $\begin{array}{l}\text { Scan this QR } \\
\text { code with your } \\
\text { smart phone or } \\
\text { mobile device } \\
\text { to read online. }\end{array}$ \\
\hline
\end{tabular}

Orientation: It is impossible to accurately determine the detailed costs of running courses offered at South African technical and vocational education and training (TVET) colleges, as none of them practises activity-based costing $(\mathrm{ABC})$. The perceptions and knowledge of their finance staff regarding $\mathrm{ABC}$ adoption are unknown, making it impossible also to know their reasons for non-adoption.

Research purpose: This article reports the awareness of and attitudes towards ABC held by finance staff at six TVET colleges in KwaZulu-Natal and proposes a novel model for its successful adoption.

Motivation for the study: The lack of empirical studies demanded understanding of those factors that address ABC adoption at South African public TVET colleges. This study therefore assessed finance staff members' perceptions of those factors that would support the introduction of this costing system.

Research approach/design and method: This study ascertained these opinions and knowledge by surveying 30 members of the finance staff at six TVET colleges using a questionnaire.

Main findings: The study's population perceived that lack of top management support, the colleges' cost structure and technical factors are barriers to the implementation of ABC in their institutions.

Practical/managerial implications: South African public colleges should address those obstructing factors as the successful adoption of $A B C$ will facilitate the accurate calculation of their operational costs.

Contribution/value-add: The study identifies those factors that would facilitate the adoption of $\mathrm{ABC}$ and proposes a model that would assist in the implementation of this costing system in South African public colleges.

Keywords: activity-based costing (ABC); traditional costing systems; technical and vocational education and training (TVET) colleges; higher education institutions (HEIs); KwaZulu-Natal (KZN).

\section{Introduction}

South African technical and vocational education and training (TVET) colleges do not use an inclusive costing instrument to determine the true and detailed costs of their courses. Such a financial mechanism would give the student and parent, as key stakeholders of these institutions, a clear view of the fees being charged as well as providing college administrations with an effective means to monitor their budgets. These institutions rely on a market-based or cost-based approach when determining their fees (Coskun \& Yilmaz 2013). However, they do not use a financial procedure that would improve the management of their finances, namely, activity-based costing $(\mathrm{ABC})$. It is therefore desirable to understand the responsible finance staff's perceptions of those factors affecting the adoption of $\mathrm{ABC}$ at these higher education institutions (HEIs). Although there is much literature on factors relating to $\mathrm{ABC}$ implementation more broadly, no studies have been conducted in South Africa that investigated the reasons for its non-introduction by TVET colleges. The aim of the study reported here therefore was to determine finance personnel's opinions of those factors that affect $\mathrm{ABC}$ adoption by these colleges in KwaZulu-Natal (KZN) province and to develop a new $\mathrm{ABC}$ model to promote its adoption. 
$\mathrm{ABC}$ is an approach to the monitoring and costing activities, which involves tracking resources consumption and costing of the products and services (Nair \& Tan 2018:133). The system assigns costs to activities based on their use of resources, and to objects based on activities they performed (Priyatmo \& Akbar 2019). In ABC, direct costs are directly traced to products or services, but the main attention is paid to indirect costs, which are allocated to activities. Although there are benefits claimed for the adoption of $A B C$, its spread and acceptance are nevertheless low compared with traditional costing systems, especially in Asia and Africa (Dandach 2015). Traditional practices use a single, volume-based cost driver, and it is argued that this distorts the costs of products (Saxena \& Vahist 2010). Commercial companies generally create a wide range of products and direct labour represents only a small percentage of total costs (Salem \& Mazhar 2010); furthermore, intense global competition has made for poor financial decision-making because of imperfect cost information obtained from traditional costing methods. In South Africa, Sartorius, Eitzen and Kamala (2007) reported that, in manufacturing companies, the adoption rate of $A B C$ is $12 \%$. Rundora and Selesho (2014) showed that in small- and medium-sized businesses, as an example, the adoption rate is one-third in the Emfuleni Municipality. In the education and training sector worldwide, the adoption rate is reported to be just 9.7\% (Aldukhil 2012).

The study reported here found that not all of the factors that contribute to successful ABC adoption are present in TVET colleges, so their absence would be barriers to the adoption of this particular costing system. The finance personnel questioned in this study perceived that the lack of top management support, the colleges' cost structure and technical factors impede its implementation. These findings are novel in the TVET sector and have implications for policymakers, such as the Department of Higher Education and Training (DHET) under which these colleges fall, as more resources and training would be required to change accounting practices as recommended. These observations also have implications for practitioners who may be required to assist in the implementation of ABC. A new costing model of this kind, to act as a guide to the adoption of this costing system in public colleges in South Africa, is reported in this study.

\section{Background}

The ABC system is more useful in determining the cost of courses at HEIs than traditional costing methods (Ali 2012:96; Manuel 2011:10; Naidoo 2010:113). It has emerged as a favoured instrument that provides administrators of HEIs (and the responsible government department, in this case the DHET) with relevant and accurate costs of programmes and courses offered at these institutions (Hashim 2015). Although $\mathrm{ABC}$ is widely used in the business world, its adoption rate is very low at HEIs and it is not applied in any of the South African TVET colleges (Aldukhil 2012). Aldukhil (2012:130) also reports that only three educational and training sectors in the world use ABC.
There is a wealth of literature on factors relating to $A B C$ adoption, which include the following: technical factors (Abusalama 2008; Cohen, Venieris \& Kaimenaki 2005, Sartorius et al. 2007; Wahab, Mohamad \& Said 2018; Xu 2012) and behavioural and organisational factors (Abusalama 2008; Chongruksut 2002; Clarke, Hill \& Stevens 1999; Elagili 2015; Shields 1995). However, many of these studies relate to the application of $\mathrm{ABC}$ to profit-making manufacturing businesses and financial organisations. Very few studies have been devoted to South African HEIs, to assess the opinions and awareness of finance staff members on those factors that affect the introduction of $\mathrm{ABC}$, especially by South African public TVET colleges. Fadzil and Rababah (2012), Aldukhil (2012) and Shields (1995) argued that ABC factors applicable in one business sector may not apply in another business setting because organisational structures vary among organisations.

The costing systems currently in use at HEIs are designed mainly for compliance and reporting purposes rather than for providing the information needed for effective management. One sector that would benefit greatly from $A B C$ is higher education. At present, the costing system used at South African HEIs groups data to answer the financial reporting needs of International Financial Reporting Standards, such as how much an institution spends on salaries and benefits (Anguiano 2013). In the costing systems used at South African HEIs, only the number of students is considered as a cost driver (Abu-Tapanjeh 2008; Kim \& Ballard 2011). The actual cost to deliver post-secondary education and how those costs relate to outcomes is not known, which means that HEI administrators and the DHET are not aware of the profitability of the student at each level of a course. Overhead costs are allocated by using the number of students regardless of the relationship with the product or service. Therefore, low-volume products are undercosted, and high-volume products are over-costed. This means that HEIs do not obtain accurate programme costs because they fail to allocate overhead costs, or they use a uniform cost driver (the number of students) to assign overhead costs to work divisions, and this criterion distorts programme costs (Kim \& Ballard 2011).

\section{Benefits of activity-based costing at technical and vocational education and training colleges}

Oseifuah (2013) argues that ABC is required in the public sector, such as TVET colleges, to translate the total general ledger account balances into their work activities, as the traditional costing system that produces general ledger information is too basic to be useful in financial decisionmaking. Technical and vocational education and training colleges need to be responsive to the government's mandate to retain and graduate more students; moreover, their budgets are tight, requiring these institutions to do ever more with fewer resources. Activity-based costing offers a mechanism that can help these colleges determine the best way to meet their goals by monitoring the use of scarce resources, in particular activities to improve student retention and graduation (Hurlburt \& Kirshstein 2014). Activity-based costing records how much time is spent on specific predefined 
activities, focusing primarily on work that is performed. According to Schmelzle and Buttros (2003), the application of $\mathrm{ABC}$ in the public sector can give needed information on the cost of government services for strategic decisions, such as determining the affordability of providing these services.

\section{Literature review Theoretical framework}

Contingency theory has been widely accepted and reported in the management and accounting literature (Ismail, Zainuddin \& Sapiei 2015:22). It is based on the principle that the appropriateness of managerial controls or systems is contingent upon the environment of the organisational setting in which these systems operate and function (Fei \& Isa 2010). Abusalama (2008) argued that ABC adoption and success depend upon specific contingent factors such as product diversity, cost structure, firm size, competition and business culture. Thus, the appropriateness of any costing system is dependent on the factors embedded in the entities involved (Aldukhil 2012). Contingency theory suggests that $\mathrm{ABC}$ adoption is contingent on behavioural and organisational factors, technical factors and the features of the management accounting system. These factors are discussed next.

\section{Factors that affect activity-based costing adoption}

The factors proposed in the literature that might affect $A B C$ adoption and implementation are divided into behavioural and organisational, and technical factors, respectively. Behavioural and organisational factors consist of the size of the organisation, top management support, cost structure, product diversity, resistance to change, the presence of an internal champion and innovation, internal resource availability and training. Technical factors consist of identifying activities, grouping and aggregating these activities, assigning resources and costs to these activities and objects, and selecting cost drivers of indirect costs. Each of these factors is discussed in turn.

\section{Behavioural and organisational factors}

Behavioural and organisational factors are important to cost management practices (Fei \& Isa 2010) and are discussed in the following section.

\section{Size of organisation}

The contingency literature considers that larger organisations are generally more difficult to manage and require more specialised and integrated techniques (Drejer 2002) than smaller ones. Some researchers (e.g. Nair \& Yee 2017; Pokorna 2016) argue that the size of a company usually explains the rate of adoption of sophisticated cost accounting systems because, in general, larger size increases complexity and usually requires greater access to individuals with the knowledge to design and implement an ABC system. Similarly, Naranjo-Gil (2009:813) and Elagili (2015:50) aver that larger companies have more resources, both for management and for the development of a complex costing system, such as ABC.
Smaller organisations that lack such resources are forced to make difficult trade-offs in their investment choices and often forgo the implementation of systems, which may represent an expensive innovation such as ABC (Damanpower \& Gopalakrishnan 2001). Elhamma's (2012) study showed a positive correlation between the size of a company and the use of $\mathrm{ABC}$. Thus, size can be an important factor related to the adoption of a new system. The study reported here therefore tested whether finance personnel perceive that larger TVET colleges are more likely to adopt ABC than smaller ones.

\section{Top management support}

Management support is not only required in the preliminary stages of $\mathrm{ABC}$ implementation; rather, it is a continuous process to maintain the new system (Aldukhil 2012). According to Intakhan (2014), the role of top managers is to determine vision and policy, make decisions, solve problems, drive the organisation to growth and survival and motivate all employees involved in the application of the accounting system. Intakhan (2014) argued that the support from the administration means a level of importance, to assist both managers and anything else that is needed to drive $A B C$ to achieve the common goals. If managers focus on involvement and participation, it should lead to the success of its implementation (Hoozee \& Bruggeman 2010; Wahab et al. 2018). Al-Saidi and Gowda (2014) further averred that a lack of commitment of managers or top management support is one of the reasons for the non-adoption of $A B C$. Majid and Sulaiman (2008) concur and assert that senior management buy-in is essential for the successful introduction of ABC. There is a greater chance of success when top management supports the adoption of $A B C$ because of the freedom and support given to the system implementers (Aldukhil 2012; Elagili 2015). Accordingly, this study investigated whether finance personnel perceive that TVET colleges, which have top management support, were more likely to adopt ABC than those which lack it.

\section{Cost structure (level of overheads)}

Drury (2015), Elagili (2015) and Al-Halabi and Shaqqour (2018) argue that as overheads become an ever-larger component of product costs, they increase the distortion inherent in traditional costing systems. Veeira and Hoskin (2004) and Majid and Sulaiman (2008) considered the overhead costs of an organisation to be a factor that increased the likelihood of $\mathrm{ABC}$ being introduced. For this reason, this study investigated whether finance staff perceive that TVET colleges, which have a greater percentage of total cost as overheads than direct costs, are more likely to adopt $A B C$ than those which have a smaller percentage.

\section{Product diversity}

According to Akinyomi (2014) and Schoute (2011), product diversity is also a major factor in the adoption of $\mathrm{ABC}$. Companies that have many diverse lines are known to use this method of costing even though allocating costs to a broad 
product range is more difficult than to a narrower one. Chongruksut and Brooks (2006) attest that companies with product diversity and more production lines are more likely to use $\mathrm{ABC}$ for the allocation of overhead costs, and that this costing system has been introduced to solve the problem of increasing costing distortion because of product complexity and product diversity. Elagili (2015) argued that greater product complexity and diversity increase the costing distortions arising from traditional costing methods. This study made the assumption that product diversity is a significant factor in the adoption of ABC. Therefore, this study examined whether finance staff perceive that TVET colleges which have more product diversity are more likely to adopt $\mathrm{ABC}$ than those which have less.

\section{Resistance to change}

The implications of organisational change, such as introducing $A B C$, should be considered within organisational and cultural contexts in which the change takes place because the human factor is important in any change of conditions (Lammert \& Ehrsam 1991). From an organisational perspective, employee resistance can be a significant deterrent to organisational change (Bvumbi 2017; Folger \& Skarlicki 1999; Kumar \& Mahto 2013). Major operational adjustments or innovations, such as the implementation of $\mathrm{ABC}$, may find resistance when those changes are perceived by the employees to alter values and visions related to the existing order (Leigh 2002). Employee opposition to ABC adoption may disrupt and delay the change process, even causing failure (Dubuhlele \& Rundora 2014; Nair \& Tan 2018). Askarany and Smith (2008) claim that organisations that adopt innovative policies are more likely to use $A B C$ as such practices provide more appropriate and detailed information than that provided by the traditional costing methods. For this reason, this study tested whether finance staff perceive that TVET colleges, with employees who are open to change and innovation, are more likely to adopt $A B C$ than those who are resistant to change.

\section{Internal champion support and innovation}

According to Egan (2002) and Nair and Tan (2018), process and team integration are the key drivers for the successful implementation of new projects. The support of an individual who plays the role of champion in an organisation and the willingness of such insiders to accept and adopt innovations such as $A B C$ are important factors in the introduction of the practice (Elagili 2015). An internal champion assists employees in familiarising themselves with a new system so as to understand its importance, thereby reducing any resistance to change within the organisation (Baird, Harrison \& Reeve 2004; Nair \& Tan 2018). Elagili (2015) argued that the presence of pro-innovation staff in a business is significant as it would help in educating senior management and users about ABC. This study therefore adopted the position that the support of an internal champion can be a significant factor in the adoption of $\mathrm{ABC}$ and determined whether finance staff perceive that TVET colleges, which have high internal champion support and innovation, are more likely to adopt $A B C$ than those without such support.

\section{Internal resources' availability}

The implementation of $\mathrm{ABC}$ demands sufficient internal resources such as the time and commitment of top management, accountants and appropriately skilled employees to build ownership, knowledge and action within the company (Chongruksut 2002; Nair \& Tan 2018). Sufficient internal resources give employees the opportunity to learn about $A B C$ and its advantages and make the staff less resistant to change (Shields 1995). Lopez (2013) concludes that ABC is accurate in allocating indirect costs to activities and measuring their performance, but consumes many resources. According to Garrison and Noreen (2011), Chiarini (2012) and Lopez (2013), the process of collecting information and identifying activities for implementing $\mathrm{ABC}$ is rigorous and time-consuming, so that limited resources are seen as a major stumbling block in its adoption. For this reason, this study investigated whether the finance staff surveyed perceive that TVET colleges, which have adequate resources, are more likely to adopt $A B C$ than those which have not.

\section{Training}

Training in this context refers to the degree of appropriate instruction on the $\mathrm{ABC}$ system used to deliver knowledge to those users who are involved in its implementation (Foster \& Swenson 1997). Such training helps the institution involved to develop positive attitudes towards the introduction of ABC (Intakhan 2014) because training aims to transfer knowledge and experience in an easy-to-understand manner. Bvumbi (2017) found that training on ABC implementation is closely associated with its successful acceptance. Gurses (1999) also reported that one stage in the implementation of ABC is training. Aldukhil (2012) argued that, without training, problems can be expected during the design, implementation and use of the process. Training is thus a prerequisite to ensure that employees understand the benefits of the system and help them in their decision-making (Elagili 2015). Elagili (2015) further indicated that for the ABC model to work there needs to be training programmes, first for the administrative staff, followed by that for the implementers and users. The influence of training on $\mathrm{ABC}$ acceptance was examined by determining whether the finance staff perceive that there is a positive relationship between the two.

\section{Technical factors}

According to Abusalama (2008:175), the behavioural and organisational factors listed above may not alone explain all the reasons for the acceptance of ABC. Technical factors, which involve the identification, defining and description of activities, also need to be considered. Turney (1996) believes that technical factors - in particular, defining and describing activities - are at the heart of designing ABC. Lin (2001) conducted an investigation into how some aspects of an $\mathrm{ABC}$ system were applied by the Chinese Railway state-owned company and pointed out the technical difficulties in identifying multiple cost drivers used to allocate indirect costs to the products and services provided by the company. $\mathrm{Xu}$ (2012) and Wahab et al. (2018) concur with Lin (2001) and 
Turney (1996) by stating that a major issue critical in the adoption of $\mathrm{ABC}$ is how to identify the relevant activities and associated cost drivers at different stages of production. This study therefore examined whether the finance staff considered that technical issues are a reason for rejecting $A B C$.

\section{Research methodology}

The positivism philosophy was selected for this study. The research method was quantitative and a survey strategy was selected to assess 30 finance staff members' perceptions of those factors that affect $\mathrm{ABC}$ adoption in six public TVET colleges in KZN as well as their knowledge of the costing system. These colleges were selected from a total of nine TVET colleges in the province as they were easily accessible to the researchers, and because they were known not to practise ABC. Questionnaires which used questions from the literature (Aldukhil 2012; Hieu 1996), as well as personal knowledge of the colleges, were hand delivered to 30 finance staff members (representing the entire finance staff of five members in each of six TVET colleges) to establish their perceptions of the factors that influence the adoption of $A B C$. A purposive sampling method was thus used.

The questionnaire consisted of 98 items divided into three sections: demographic data; the $\mathrm{ABC}$ system and knowledge about it; and factors affecting adoption of $\mathrm{ABC}$. To obtain both valid and reliable measurements, all questions for the survey were designed to cover only one aspect at a time, they were phrased concisely to avoid ambiguity and they were made easily comprehensible. The questionnaire was pre-tested by using a sample of finance members from EThekwini TVET college in Durban to eliminate any bias.

A Likert-type scale of 1 = 'strongly agree', 2 = 'agree', $3=$ 'neutral', 4 = 'disagree' and 5 = 'strongly disagree' was used. The completed questionnaires were checked to ensure that the data recorded were usable. Thereafter, the responses were coded and captured in SPSS version 24.0.

Cronbach's $\alpha$ was used to measure the internal consistency of the survey response scale. A low value of alpha could be because of a small number of questions in a response scale (Tavakol \& Dennick 2011). Spiliotoulou (2009) reported that probably the small number of items in each response scale resulted in 'relatively moderate coefficients'. Voss, Stem and Fotopoulos (2000) state that the Cronbach's $\alpha$ estimation of reliability increases with scale length (i.e. the number of items in a response scale). Other researchers have explained a small alpha $(\alpha=0.40)$ as the result of small sample size and agree that maximising the number of participants responding to a response scale can increase the amount of covariance among item responses (Lane \& Zivian 2003; Helms et al. 2006).

Reliability tests performed in this study, as shown in Table 1, were conclusive for all the questionnaire items, except for one response scale that deals with the efficiency of current costing system (Csronbach's $\alpha>0.6$ ). All other four Cronbach's $\alpha$ values shown in Table 1 were acceptable based on the sample size of the study. Cronbach's $\alpha<0.6$ in the scale that deals with the efficiency of current costing system was also acceptable, considering the minimum number of statements that constituted this section.

\section{Ethical consideration}

This article adhered to all ethical standards to hold the integrity of the research. Ethical approval was obtained from Durban University of Technology (Ethical clearance number: IREC 018/16) on 21 September 2016.

\section{Research findings and discussion}

The study population's awareness of $A B C$ and their opinions about factors that affect its adoption were established from the responses to the questionnaire. Before addressing respondents' perceptions of the factors which may affect $\mathrm{ABC}$ adoption, the samples were asked to indicate their level of understanding of the practice. Most of the respondents had some experience of $\mathrm{ABC} ; 18(60 \%)$ indicated that they had some awareness of it, whereas $12(40 \%)$ reported that they had no such knowledge. Among the 30 respondents, just one claimed to have 'expert knowledge', 6 professed to 'extensive knowledge', 11 thought they had a 'general knowledge' of $\mathrm{ABC}$ and 12 claimed 'no knowledge at all'.

Although this study reported that some staff personnel were not familiar with $A B C$, this may have referred to enough knowledge to implement $\mathrm{ABC}$, as none of the six colleges had implemented $\mathrm{ABC}$. Their responses to the question on current ABC implementation during assessment showed 18 (60\%) respondents, indicating that their colleges were not presently thinking about switching to ABC. A total of $8(27 \%)$ reported that $\mathrm{ABC}$ was currently under consideration at their institution, and $4(13 \%)$ replied that the system had been rejected after assessment. Although $A B C$ had not been introduced at any of the six colleges surveyed, their finance staff were generally aware of the reasons that could lead their colleges to accept or reject ABC. Accordingly, their finance staff members were asked to indicate their perceptions of the various factors that can influence its adoption. These perceptions are discussed below.

\section{Behavioural and organisational factors}

\section{Size of organisation}

Of the 30 finance personnel surveyed, 26 (87\%) agreed that larger colleges were more likely to introduce a new costing

TABLE 1: Cronbach's $\alpha$.

\begin{tabular}{lcc}
\hline Variables & Number of items & Cronbach's $\alpha$ \\
\hline $\begin{array}{l}\text { Determining the costing model at TVET colleges } \\
\begin{array}{l}\text { Determining the efficiency of current costing } \\
\text { system }\end{array}\end{array}$ & 5 & 0.679 \\
$\begin{array}{l}\text { Internal resistance to a new system } \\
\begin{array}{l}\text { Determining critical success factors for ABC } \\
\text { implementation }\end{array}\end{array}$ & 2 & 0.519 \\
$\begin{array}{l}\text { Determining technical factors that constitute } \\
\text { barriers to ABC adoption }\end{array}$ & 4 & 0.630 \\
\begin{tabular}{l} 
Overall \\
\hline
\end{tabular} & 22 & 0.715 \\
\hline
\end{tabular}

TVET, technical and vocational education and training; $A B C$, activity-based costing. 
system as they would probably have greater access to individuals with knowledge of its implementation. The differences between the respondents' replies were statistically significant ( $\left.p=0.001, \chi^{2}=17.467, d f=3\right)$. This contradicts the findings of Nair and Yee (2017), Pokorna (2016), Elagili (2015), Elhamma (2012) and Naranjo-Gil (2009); the size of the organisation appeared not to be a significant factor in the adoption of $\mathrm{ABC}$. It therefore appeared that the finance staff believed that their colleges were large enough to introduce $\mathrm{ABC}$ because they have the potential to recruit individuals with the necessary knowledge. However, in this study all six TVET colleges do not practise $\mathrm{ABC}$, so the size of the organisation has not played a role in its adoption.

\section{Top management support}

The second factor adopts the position that top management support is a significant factor in the adoption of $A B C$. Three statements were used to test this factor (Table 2). Half (15) of the respondents were neutral in their attitudes to the statement: 'Top management always provide adequate support when a new system or programme is introduced'; 12 (40\%) were neutral in their attitudes to the second statement: 'Top management always consult affected staff for their input and opinion before introducing a new system'. There was only modest support from the respondents for both statements. The third statement, 'Top management always conduct proper skills audits to ascertain the competency gap before they introduce a new system', was not supported by the majority of the respondents, with 13 (43\%) disagreeing with the statement and $10(33 \%)$ reporting a neutral stance. The first two statements which tested as significant indicate that the study population does not perceive that there is top management support when a new system is introduced nor that affected staff are consulted or skills audits conducted. This may indicate that lack of top management support for a new system is a barrier to the adoption of ABC. This is consistent with the findings of Wahab et al. (2018) and of Majid and Sulaiman (2008).

\section{Level of overheads}

The respondents were asked to indicate the cost structure at their colleges. They reported that direct labour represented the highest cost element, averaging across all colleges at $57.9 \%$ of total costs, followed by direct material $(21.8 \%)$ and overheads $(20.3 \%)$ costs. Thus, colleges are clearly labour intensive, which could have a negative influence on the adoption of ABC.

Table 3 shows a cross-tabulation between ABC adoption and cost structure. If there is no relationship between $A B C$ adoption and cost structure, Table 3 would show the same cost distribution within each group. Two cross-tabulations ('low overheads' and 'currently under consideration', and 'low overheads' and 'no consideration of $\mathrm{ABC}$ to date') represent the majority opinions of the finance staff. This last cross-tabulation could indicate that the low level of overheads is a reason for the non-adoption of $A B C$ and could be perceived as a barrier to its implementation. This study concludes that cost structure is a significant factor in ABC adoption, which corroborates the findings in the literature (Al-Halabi \& Shaqqour 2018; Drury 2015; Majid \& Sulaiman 2008; Veeira \& Hoskin 2004).

\section{Product diversity}

Colleges with more courses on offer are more likely to adopt ABC (Chongruksut \& Brooks 2006). To determine product diversity in terms of the number of courses available, the survey group were first asked to indicate the corresponding number of courses, using three levels of answers representing $1-10,11-30$ and more than 30 courses, respectively. Table 4 shows a cross-tabulation between product diversity and involvement of the colleges in ABC adoption.

Table 4 shows that at colleges with medium product diversity, 13 respondents indicated that $\mathrm{ABC}$ was not being considered, whereas seven reported that it was currently under review. However, a specific question posed on product diversity (i.e. offering of more courses) indicated that the respondents believed that the colleges with more courses on offer are more likely to accept a new costing system. Twenty-one (70\%) agreed that they would, revealing a significant relationship between product diversity and acceptance of a

TABLE 3: Overheads and involvement of colleges in activity-based costing adoption. What is the current level The approximate percentage of total costs Total of $A B C$ adoption in your accounted for each of the following college?

\begin{tabular}{|c|c|c|c|c|c|c|c|c|}
\hline \multirow[t]{2}{*}{ ondo. } & \multicolumn{2}{|c|}{$\begin{array}{l}\text { Low } \\
\text { overheads }\end{array}$} & \multicolumn{2}{|c|}{$\begin{array}{l}\text { Medium } \\
\text { overheads }\end{array}$} & \multicolumn{2}{|c|}{$\begin{array}{c}\text { High } \\
\text { overheads }\end{array}$} & \multirow[b]{2}{*}{$N$} & \multirow[b]{2}{*}{$\%$} \\
\hline & $N$ & $\%$ & $N$ & $\%$ & $N$ & $\%$ & & \\
\hline Implemented in selected areas & 1 & 33 & 0 & 0 & 2 & 67 & 3 & 10 \\
\hline Currently under consideration & 8 & 100 & 0 & 0 & 0 & 0 & 8 & 27 \\
\hline Rejected $A B C$ after assessment & 0 & 0 & 0 & 0 & 1 & 100 & 1 & 3 \\
\hline $\begin{array}{l}\text { No considera-tion of } A B C \text { to } \\
\text { date }\end{array}$ & 17 & 94 & 1 & 6 & 0 & 0 & 18 & 60 \\
\hline Total & 26 & 100 & 1 & 100 & 3 & 100 & 30 & 100 \\
\hline Total \% & - & 86.7 & - & 3.3 & - & 10 & - & 100 \\
\hline
\end{tabular}

Note: $N$ indicates how many respondents indicated each level of overheads (low-high overheads) under each level of $A B C$ adoption (under consideration-no consideration). $\%$ indicates the percentage respondents within the level of $A B C$ adoption in each level of overhead out of the total respondents in $N$ column. The column 'Total' under each level of $\mathrm{ABC}$ adoption indicates total number of respondents (e.g. 3 in first row) responded under each level of $A B C$ adoption out of those included in data sample (i.e. 30 finance personnel). $A B C$, activity-based costing.

\begin{tabular}{|c|c|c|c|c|c|c|c|c|c|}
\hline \multirow[t]{2}{*}{ Statements } & \multicolumn{2}{|c|}{ Agree } & \multicolumn{2}{|c|}{ Neutral } & \multicolumn{2}{|c|}{ Disagree } & \multirow[t]{2}{*}{$\chi^{2}$} & \multirow[t]{2}{*}{$d f$} & \multirow[t]{2}{*}{ (Asymp. sig.) $p$} \\
\hline & $n$ & $\%$ & $n$ & $\%$ & $n$ & $\%$ & & & \\
\hline $\begin{array}{l}\text { Top management always provide adequate support when a new } \\
\text { system or programme is introduced. }\end{array}$ & 8 & 27 & 15 & 50 & 7 & 23 & 12.400 & 3 & $0.006 *$ \\
\hline $\begin{array}{l}\text { Top management always consult affected staff for their input and } \\
\text { opinion before introducing a new system. }\end{array}$ & 7 & 23 & 12 & 40 & 11 & 37 & 9.200 & 3 & $0.027 *$ \\
\hline $\begin{array}{l}\text { Top management always conduct proper skills audits to ascertain } \\
\text { the competency gap before they introduce a new system. }\end{array}$ & 7 & 23 & 10 & 33 & 13 & 43 & 9.000 & 4 & 0.061 \\
\hline
\end{tabular}

$*, p<0.05$. 
new system $\left(\chi^{2}=34.000\right.$, d.f. $=4$ and $\left.p \leq 0.001\right)$ - that is, the greater the number of courses on offer, the more likely a college would be to accept a new system. This finding reflects the work of Elagili (2015), Akinyomi (2014), Schoute (2011) and Chongruksut and Brooks (2006), all of whom found a positive relationship between product diversity and $A B C$ adoption.

\section{Resistance to change}

Resistance to change appears to be a critical factor in the adoption of ABC. Respondents' attitudes in this respect are shown in Table 5. The first four statements indicate that the respondents agreed that they were open to a new system that has advantages and if training is provided. In the last six statements, the respondents expressed disagreement with statements suggesting that even though the change may have benefits, they may still avoid or resist it, or prefer to do things in the way they are used to. The answers to most statements had statistically significant differences, which supported either the acceptance or rejection of the corresponding statement. It is apparent here that although respondents may be comfortable with the costing system they know, they can readily switch to a new system when its likely benefits are known. However, overall, the personnel surveyed indicated that they were open to change and should

TABLE 4: Product diversity and involvement in activity-based costing adoption.

\begin{tabular}{|c|c|c|c|c|c|c|c|c|}
\hline \multirow{3}{*}{$\begin{array}{l}\text { What is the } \\
\text { current level of } \\
\text { ABC adoption in } \\
\text { your college? }\end{array}$} & \multicolumn{6}{|c|}{ How many courses does your college offer? } & \multirow{2}{*}{\multicolumn{2}{|c|}{ Total }} \\
\hline & \multicolumn{2}{|c|}{$\begin{array}{l}\text { Low product } \\
\text { diversity } \\
(1-10)\end{array}$} & \multicolumn{2}{|c|}{$\begin{array}{c}\text { Medium } \\
\text { product diversity } \\
(11-30)\end{array}$} & \multicolumn{2}{|c|}{$\begin{array}{l}\text { High product } \\
\text { diversity } \\
(>30)\end{array}$} & & \\
\hline & $N$ & $\%$ & $N$ & $\%$ & $N$ & $\%$ & $N$ & $\%$ \\
\hline $\begin{array}{l}\text { Currently under } \\
\text { consideration }\end{array}$ & 0 & 0 & 7 & 88 & 1 & 12 & 8 & 27 \\
\hline $\begin{array}{l}\text { Rejected } A B C \\
\text { after assessment }\end{array}$ & 0 & 0 & 3 & 75 & 1 & 25 & 4 & 13 \\
\hline $\begin{array}{l}\text { No consideration } \\
\text { of } A B C \text { to date }\end{array}$ & 2 & 11 & 13 & 72 & 3 & 17 & 18 & 60 \\
\hline Total & 2 & 100 & 23 & 100 & 5 & 100 & 30 & 100 \\
\hline Total \% & - & 7 & - & 77 & - & 16 & - & 100 \\
\hline
\end{tabular}

Note: $N$ indicates how many respondents indicated each level of product diversity (low-high) under each level of $A B C$ adoption (under consideration-no consideration). \% indicates the under each level of $A B C$ adoption (under consideration-no consideration). \% indicates the percentage respondents within the level of ABC adoption in each level of product diversity out
of the total respondents in $N$ column. The column 'Total' under each level of ABC adoption of the total respondents in $N$ column. The column 'Total' under each level of $A B C$ adoption
indicates total number of respondents (e.g. 18 in third row) responded under each level of ABC indicates total number of respondents (e.g. 18 in third row) responded under
adoption out of those included in data sample (i.e. 30 finance personnel).

$A B C$, activity-based costing. therefore accept a new costing system. This is inconsistent with the general findings in prior research such as that by Bvumbi (2017), Kumar and Mahto (2013), Folger and Skarlicki (1999), Leigh (2002) and Askarany and Smith (2008), all of whom found a positive relationship between employee resistance and $\mathrm{ABC}$ adoption. It is also clear that resistance to change could only be encountered in respect of the introduction of $\mathrm{ABC}$ if its objectives and benefits are not well communicated at the time of its proposal.

\section{Internal champion support and innovation}

The support of an internal champion in an organisation is a significant factor in the adoption of $\mathrm{ABC}$. In response to the statement, 'If there is a new system intended to improve efficiency, I will encourage and support its implementation', 29 (97\%) participants agreed that they would, one was neutral and no one disagreed. Thus, representatives of the finance staff are willing to act as internal champions if a novel procedure was introduced to improve efficiency. This is contradictory to the findings of Nair and Tan (2018), Elagili (2015) and Baird et al. (2004) that an internal champion and innovation are important factors in the adoption of ABC, as in this situation, none of the TVET colleges have adopted a new system such as $\mathrm{ABC}$.

\section{Internal resources' availability}

The availability of internal resources, such as experienced finance staff, is a significant factor in the adoption of ABC. Over half $(53 \%)$ of those surveyed agreed that their finance department is adequately staffed and retains trained and experienced staff. However, their colleges are not ABC users. This finding could imply that there is no relationship between experienced personnel and ABC adoption, based on the fact that these colleges are well-resourced with sufficient and appropriate skills of chartered accountants who are responsible for the finance department in TVET colleges in South Africa, and who could handle the adoption and implementation of ABC. This result would be contradictory to the findings by Nair and Tan (2018), Garrison and Noreen (2011), Chongruksut (2002) and Shields (1995) that limited resources impede $\mathrm{ABC}$ adoption.

TABLE 5: Resistance to change.

\begin{tabular}{|c|c|c|c|c|c|c|c|c|c|}
\hline \multirow[t]{2}{*}{ Statements } & \multicolumn{2}{|c|}{ Agree } & \multicolumn{2}{|c|}{ Neutral } & \multicolumn{2}{|c|}{ Disagree } & \multirow[t]{2}{*}{$\chi^{2}$} & \multirow[t]{2}{*}{$d f$} & \multirow{2}{*}{${ }_{(\text {Asymp. sig.) }}$} \\
\hline & $N$ & $\%$ & $N$ & $\%$ & $N$ & $\%$ & & & \\
\hline I am open to a new system which reduces errors. & 27 & 90 & 2 & 7 & 1 & 3 & 19.867 & 3 & $0.000 *$ \\
\hline I accept a system which leads to a better adherence to policies and procedures. & 27 & 90 & 1 & 3 & 2 & 7 & 20.933 & 3 & $0.000 *$ \\
\hline $\begin{array}{l}\text { I am open to a new system if it allocates costs, and is more efficient than the old way } \\
\text { of doing things. }\end{array}$ & 25 & 83 & 5 & 16 & - & 0 & 5.000 & 2 & 0.082 \\
\hline I am open to the new system if adequate training is received. & 24 & 80 & 2 & 7 & 4 & 13 & 20.000 & 4 & $0.000 *$ \\
\hline Often, I feel uncomfortable about change that may even potentially improve my life. & 3 & 10 & 8 & 28 & 18 & 62 & 5.897 & 3 & 0.117 \\
\hline $\begin{array}{l}\text { When someone pressures me to change something, I tend to resist it even if I think the } \\
\text { change may ultimately benefit me. }\end{array}$ & 1 & 3 & 6 & 21 & 22 & 76 & 19.414 & 3 & $0.000 *$ \\
\hline I sometimes find myself avoiding changes that I know will be good for me. & - & 0 & 3 & 10 & 26 & 90 & 10.207 & 2 & $0.006^{*}$ \\
\hline Once I come to a conclusion, I'm not likely to change my mind. & 2 & 7 & 7 & 24 & 20 & 69 & 22.897 & 4 & $0.000 *$ \\
\hline I like to do the same old things rather than try new and different ones. & 1 & 3 & 4 & 14 & 24 & 83 & 17.483 & 3 & $0.001 *$ \\
\hline $\begin{array}{l}\text { If I were to be informed that there's going to be a significant change regarding the ways } \\
\text { things are done at work, I would probably feel stressed. }\end{array}$ & 2 & 7 & 7 & 24 & 20 & 69 & 17.379 & 4 & $0.002 *$ \\
\hline
\end{tabular}

Note: Some statements were answered by only 29 respondents.

$*, p<0.05$. 


\section{Training}

Respondents were asked whether adequate training is provided when a new system is implemented. Of those surveyed, $13(43 \%)$ indicated that sufficient training is not provided, $6(20 \%)$ were neutral on the subject and $11(37 \%)$ indicated that such training is available. The $\chi^{2}$ test indicated that there was a statistically significant difference in the responses $(p<0.05)$. Lack of training is therefore seen as a barrier to the adoption of a new system, and could be inferred as a barrier to the adoption to ABC. Prior research reveals that training on $\mathrm{ABC}$ implementation is closely associated with its adoption (Bvumbi 2017; Elagili 2015; Gurses 1999; Intakhan 2014). However, in this study all six TVET colleges do not practise $\mathrm{ABC}$, so training has not played a part in its adoption (or the adoption of any other new system) by them.

\section{Technical factors}

Technical factors are of importance in the adoption of ABC. The respondents were therefore asked to indicate their level of agreement with the following three statements. They disagreed with the first statement: 'I can rank all the tasks of the college according to the college's divisions'. However, respondents were in agreement with the second statement: 'I can list all tasks and duties that I perform in my job'. This may indicate that the participants are focused more on their jobs than on the tasks of the college. This is supported by the last statement, about which respondents were mainly neutral, or disagreed, that they could 'break down the time spent on major activities performed at campus level'. The survey group also disagreed with the notion that their colleges identify and analyse the various activities relating to students, such as services and teaching. For three of the statements, there was a significant difference $(p<0.05)$ between the responses. In summary, these results indicate that technical factors could be a barrier to the introduction of $\mathrm{ABC}$ at the colleges as the respondents were more knowledgeable about their own tasks than the tasks of the college itself. Finance staff members in the KZN colleges could not categorise tasks as per division and their respective institutions, nor could they identify and analyse various activities involved with providing services or teaching students and break down time spent on major activities performed at campus level. Understanding the tasks of the college would be necessary to implement a new system, such as ABC. This finding is consistent with the conclusions reached by Wahab et al. (2018), Xu (2012), Abusalama (2008), Lin (2001) and Turney (1996) that there is a positive relationship between technical factors and $\mathrm{ABC}$ adoption. Although these colleges have some competent finance staff members, ongoing support along with sufficient training is needed in the technical issues of $\mathrm{ABC}$ implementation.

\section{Proposed new activity-based costing model}

This study indicates that the adoption of $\mathrm{ABC}$ is contingent upon two behavioural and organisational factors (top management support and institutional cost structure [overhead level]), and technical factors (identifying activities, and then grouping and assigning costs to them). Current $A B C$ models aver that only the technical factors need to be addressed together with organisational structure and culture (Fei \& Isa 2010). The new ABC model proposed here is based on the belief that, to adopt $\mathrm{ABC}$ successfully, the possible lack of top management support factors must be identified first and addressed; thereafter, technical factors and overhead level must be taken into account (Figure 1). The model incorporates a logical flow of relationships that culminates with the adoption of $\mathrm{ABC}$.

This model proposes that TVET colleges that address only technical factors and organisational cost structure without considering top management support may be unsuccessful in dealing with any implementation issues.

\section{Conclusions, recommendations and limitations}

This study indicates that not all of the factors identified as being relevant are present at the six TVET colleges surveyed, and therefore their absence would act as barriers to the adoption of $A B C$. The finance staff questioned perceived that the lack of top management support and their colleges' cost structure are barriers to the costing system's implementation. Technical factors were also shown to be barriers to $A B C$ acceptance. It is therefore important to identify whether all the necessary factors are present in any organisation seeking to adopt the costing practice. This supports contingency theory's premise that no single type of organisational structure is equally applicable to all entities (Aldukhil 2012). Although current ABC models suggest that only the technical factors need to be addressed together with organisational structure and culture (Fei \& Isa 2010), the implications of this study are that, to introduce $A B C$, a new model is required in which the lack of top management support should be addressed first and thereafter any technical factors and organisational cost structure (overhead level) necessary. These findings are novel in the TVET sector and have implications for policymakers, such as the DHET, the branch of government responsible for these colleges, as provision would need to be made for more resources and training opportunities. These conclusions also have implications for practitioners who may be required to assist in the implementation of $\mathrm{ABC}$.

A limitation of this study is that it focused on the adoption of $\mathrm{ABC}$ in just six TVET colleges in $\mathrm{KZN}$, and as a result the

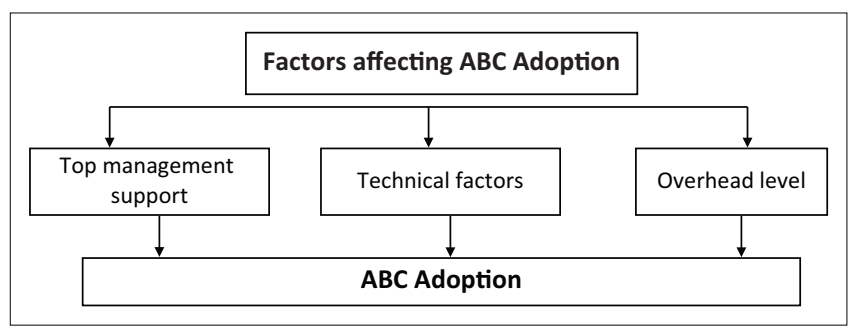

$A B C$, activity-based costing.

FIGURE 1: Proposed new activity-based costing model. 
level of statistical testing was comparatively simple. Furthermore, the results of this study may not be generalised beyond this group. However, it is believed that these findings are more widely appropriate beyond the study group. To overcome this limitation, a larger sample (e.g. the 44 other public TVET colleges in South Africa) could be used to test the findings of this study. Moreover, the proposed ABC model can be evaluated in a specific $A B C$ non-adopter sector as proposed here, particularly the government sector in South Africa. That may provide additional insights into whether a new model would enable identification of all adoption factors identified here and assist in the introduction of $\mathrm{ABC}$.

\section{Acknowledgements}

A preliminary draft of the article was presented at the 30th Southern African Institute of Management Scientists Conference, hosted by the Department of Management at Stellenbosch University on 16-19 September 2018 and included in the conference proceedings. This article is also the outcome of a master's dissertation submitted to Durban University of Technology by M.C. Madwe under the supervision of L.J. Stainbank and P.E. Green, the co-authors.

\section{Competing interests}

The authors declare that they have no financial or personal relationships that may have inappropriately influenced them in writing this article.

\section{Authors' contributions}

P.E.G. designed the study, M.C.M. conducted the survey and wrote the article and L.J.S. analysed the results.

\section{Funding information}

This research received no specific grant from any funding agency in the public, commercial or not-for-profit sectors.

\section{Data availability statement}

Data sharing is not applicable to this article as no new data were created or analysed in this study.

\section{Disclaimer}

The views and opinions expressed in this article are those of the authors and do not necessarily reflect the official policy or position of any affiliated agency of the authors.

\section{References}

Abusalama, F.D., 2008, 'Barriers to adoption of activity based costing. An empirical investigation in Irish top 1000 companies in business and finance using cluster analysis', PhD thesis, Dublin Institute of Technology, Dublin, Ireland.

Abu-Tapanjeh, A.M., 2009, 'Corporate governance from the Islamic perspective: A comparative analysis with OECD principles', Critical Perspectives on Accounting 20, 556-567. https://doi.org/10.1016/j.cpa.2007.12.004

Akinyomi, O.J., 2014, 'Effects of product diversity on activity based costing implementation in Nigeria', International Journal of Technology Marketing 4(2), 46-54.
Aldukhil, Y., 2012, 'Developing and testing a model of successful adoption of activity based costing', PhD thesis, Victoria University, Melbourne.

Al-Halabi, N.B. \& Shaqqour, O.F., 2018, 'The effect of activity based costing on managing the efficiency of performance in Jordanian Manufacturing Corporation: Analytical study', Accounting and Finance Research 7(1), 262-270. https://doi. Analytical study, Accounting
org/10.5430/afr.v7n1p262

Ali, Y.Q., 2012, 'Investigating the cost of education per-student using activity based costing (ABC) system in Islamic Azad University Qaemshahr Branch', American Journal of Scientific Research 62(1), 94-100.

Al-Saidi, M.S.H. \& Gowda, H.N., 2014, 'Measure of activity based costing: A review', International Journal of Research in Commerce, IT \& Management 4(5), 10-12.

Anguiano, M., 2013, Cost structure of post-secondary, viewed 23 August 2017, from https://maximizingresources.org/files/cost-structure-of-post-secondary.

Askarany, D. \& Smith, M., 2008, 'Diffusion of innovation and business size: A longitudinal study of PACIA', Managerial Auditing Journal 23(9), 900-916. https:// doi.org/10.1108/02686900810908445

Baird, M.K., Harrison, G.L. \& Reeve, R.C., 2004, 'Adoption of activity based management practices: A note on the extent of adoption and influence of organisational and cultural factors', Journal of Management Accounting Research 15, 383-399. https://doi.org/10.1016/j.mar.2004.07.002

Bvumbi, M.N., 2017, 'An analysis of the implementation of activity based costing at the water trading entity', Master's degree, University of South Africa.

Chiarini, A., 2012, 'Lean production: Mistakes and limitations of accounting systems inside the SME sector', Journal of Manufacturing Technology Management 23(5), 681-700. https://doi.org/10.1108/17410381211234462

Chongruksut, W., 2002, 'The adoption of activity based costing in Thailand', PhD thesis, Victoria University, Melbourne.

Chongruksut, W. \& Brooks, A., 2006, 'The adoption and implementation of activity based costing in Thailand', Asian Review of Accounting 13(2), 1-17. https://doi. org/10.1108/eb060784

Clarke, P., Hill, N. \& Stevens, K., 1999, 'Activity based costing in Ireland: Barriers to and opportunities for change', Critical Perspectives on Accounting 10, 443-468. https://doi.org/10.1006/cpac.1997.0197

Cohen, S., Venieris, G. \& Kaimenaki, E., 2005, 'ABC: Adopters, supporters, deniers and unawares', Managerial Auditing Journal 9, 981-1000. https://doi.org/ 10.1108/02686900510625325

Coskun, A. \& Yilmaz, M., 2013, 'Pricing decisions in educational institutions: An activity based costing approach', in 4th International Conference on New Horizon in Education, June 30, 2013, Sakarya Universitesi, Elsevier, Serdavan, Turkey, pp. 2112-2118.

Damanpower, F. \& Gopalakrishna, S., 2001, 'The dynamic of the adoption of product and process innovations in organisations', Journal of Management Studies 38 45-65. https://doi.org/10.1111/1467-6486.00227

Dandach, G.A., 2015, The reasons behind the non-application of activity based costing system in the service industry in Lebanon, Business Administration, Lebanese American University, Lebanon.

Drejer, A., 2002, 'Situations for innovation management: Towards a contingency model', European Journal of Innovation Management 5(1), 4-17. https://doi. org/10.1108/14601060210415135

Drury, C., 2015, Management and cost accounting, Cengage Learning, North Way.

Dubuhlele, J. \& Rundora, R., 2014, 'Employee training, managerial commitment and the implementation of activity based costing: Impact on performance of SMEs', International Business \& Economics Research Journal 13(1), 27-37. https://doi. org/10.19030/iber.v13i1.8354

Egan, G., 2002, The Skilled Helper: A problem-management and opportunitydevelopment approach to helping, Brook Cole, Pacific Grove, CA.

Elagili, G., 2015, 'Adoption factors for the implementation of activity based costing systems: A case study of Libyan cement industry', PhD thesis, University of Salford, Salford.

Elhamma, A., 2012, 'The relationship between firm's size, activity based costing and performance: An application on Moroccan enterprises', Journal of Accounting Business and Management 19(1), 90-102.

Fadzil, F.H. \& Rababah, A., 2012, 'Management accounting change: ABC adoption and implementation', Journal of Accounting and Auditing 2012, 1-17. https://doi. org/10.5171/2012.349927

Fei, P. \& Isa, C., 2010, 'Factors influencing activity based costing success: A research framework', International Journal of Trade, Economics and Finance 1(2), 144-150. https://doi.org/10.7763/IJTEF.2010.V1.26

Folger, R. \& Skarlicki, D.P., 1999, 'Unfairness and resistance to change: Hardship as mistreatment', Journal of Organisational Change Management 12(1), 35-50. https://doi.org/10.1108/09534819910255306

Foster, G. \& Swenson, D., 1997, 'Measuring success of activity based costing management and its determinants', Journal of Management Accounting Research 9, 109-141.

Garrison, R.H. \& Noreen, E.W., 2011, Management accounting, Irwin McGraw-Hill, New York.

Gurses, A., 1999, 'An activity based costing and theory of constraints model for product-mix decisions', Master's dissertation, Virginia Polytechnic Institute and State University. 
Hashim, J.H., 2015, 'The activity-based costing in institutions of higher education: Do private and public bring a different?', Asian Journal of Basic \& Applied Sciences 2(1), 16-30.

Helms, J.E., Henze, K.T., Sass, T.L. \& Mifsud, V.A., 2006, 'Treating Cronbach's alpha reliability coefficients as data in counselling research', The Counselling Psychologist 34(5), 630-660. https://doi.org/10.1177/0011000006288308

Hieu, N., 1996, 'An investigation as to why companies do not adopt activity based costing', Master's dissertation, Victoria University of Technology.

Hoozee, S. \& Bruggeman, W., 2010, 'Identified operation improvement during the design process of a time driven $A B C$ system: The role of collective worker participation and leadership style', Management Accounting Research 21 185-198. https://doi.org/10.1016/j.mar.2010.01.003

Hurlburt, S. \& Kirshstein, R., 2014, 'The activity based costing in community colleges', viewed 23 August 2017, from http://www.maximizingresources.org/files/The ABCs-of-activity-based-costing-in-community-colleges.pdf.

Intakhan, P., 2014, 'Direct \& indirect effects of top management support on ABC implementation success: Evidence from ISO 9000 certified companies in Thailand', in International Conference on Accounting Studies 2014, ICAS 2014, August 18-19, Kuala Lumpur, Malaysia, pp. 458-470.

Ismail, K., Zainuddin, S. \& Sapiei, N.S., 2015, 'The use of contingency theory in management and accounting research', Journal of Accounting Perspective 8(1) 23-37.

Kim, Y. \& Ballard, G., 2011, 'A case study of activity based costing in allocating rebar fabrication costs to project', Construction Management and Economics Journal 29(5), 449-461. https://doi.org/10.1080/01446193.2011.570354

Kumar, N. \& Mahto, D., 2013, 'Current trends of application of ABC: A review', Global Journal of Management and Business Research 13(3), 1-15.

Lammert, T.B. \& Ehrsam, R., 1991, The human element: The real challenge in modernizing cost systems, Prentice Hall, Atlantic City, NJ.

Lane, A. \& Zivian, J., 2003, 'Assessing children's competence in computer interactions: Preliminary reliability and validity of the test of mouse proficiency', Occupation ParticipationandHealth23(1),18-26.https://doi.org/10.1177/153944920302300103

Leigh, K.E., 2002, 'Case study: Identifying resistance in managing change', Journal of Organisational Change Management 15(2), 138-155. https://doi.org/10.1108/ 09534810210423044

Lin, B., 2001, 'A case study of ABC in Chinese railway', Journal of Accounting Research (China) 2, 31-39.

Lopez, P.R., 2013, 'Lean manufacturing: Costing the value stream', Industrial Management and Data Systems 113(5), 647-668. https://doi.org/10.1108/02635571311324124

Majid, A. \& Sulaiman, M., 2008, 'Implementation of activity based costing in Malaysia: A case study of two companies', Asian Review of Accounting 16(1), 39-55. https://doi.org/10.1108/13217340810872463

Manuel, C., 2011, 'The Applicability of the principles of activity based costing system in a Higher Education Institution: Economics and management research projects', An International Journal 1(1), 57-65.

Naidoo, M., 2010, 'Using activity based costing to manage private universities in South Africa', Problems and Perspectives in Management 9(4), 109-115.

Nair, S. \& Tan, X., 2018, 'Factors influencing the implementation of activity based costing: A study on Malaysian SMEs', International Business Research 11(8), 133-141. https://doi.org/10.5539/ibr.v11n8p133

Nair, S. \& Yee, S.N., 2017, 'Factors affecting management accounting practices in Malaysia', International Journal of Business and Management 12(10), 177-184.
Naranjo-Gil, D., 2009, 'The influence of environment and organisational factors on innovation adoption: Consequences for performance in public sectors', Technovation 29, 810-818. https://doi.org/10.1016/j.technovation sectors', Techno
2009.07.003

Oseifuah, E.K., 2013, 'Activity based costing approach to financial management in the public sector', European Scientific Journal 9(1), 35-53.

Pokorna, J., 2016, 'Impact of activity based costing on financial performance in the Czech Republic', Acta Universitatis Agriculturae et Silviculturae Mendelianae Brunensis 64(2), 643-652. https://doi.org/10.11118/actaun201664020643

Priyatmo, T. \& Akbar, A., 2019, 'Analysis of the prospect of implementing activitybased costing in governmental organisations: A study at the State Treasury Office Jakarta', Journal of Accounting and Investment 20(1), 1-22. https://doi. org/10.18196/jai.2001105

Rundora, R. \& Selesho, J., 2014, 'Determinants of and barriers to the adoption of activity based costing for manufacturing SMEs in South Africa's Emfulen Municipality', Mediterranean Journal of Social Sciences 5(3), 30-35. https://doi. org/10.5901/mjss.2014.v5n3p30

Salem, S.E.A. \& Mazhar, S., 2014, 'The benefits of the application of activity based costing on manufacturing companies operating in Allahabad City - India', Journa of Business and Management 16(2), 23-27.

Sartorius, K., Eitzen, P. \& Kamala, P., 2007, 'The design and implementation of activity based costing (ABC): A South African survey', Meditari Accountancy Research 15(2), 1-21. https://doi.org/10.1108/10222529200700008

Saxena, V.K. \& Vahist, C.D., 2010, Essentials of cost accounting, Sultan Chad \& Sons, Mumbai.

Schmelzle, G. \& Buttros, T., 2003, 'The Hidden cost JIT cost-MAAW', Journal of Cost Management March/April, 23-27.

Schoute, M., 2011, 'The relationship between product diversity, usage of advanced manufacturing technology and activity-based costing', British Accounting Review 43(2), 120-134. https://doi.org/10.1016/j.bar.2011.02.002

Shields, M., 1995, 'An empirical analysis of firms' implementation experiences with activity based costing', Journal of Management Accounting Research 7, 148-166.

Spiliotoulou, G., 2009, 'Reliability reconsidered: Cronbach's alpha and paediatric assessment in occupational therapy', Australian Occupational Therapy 56(3), 150-155. https://doi.org/10.1111/j.1440-1630.2009.00785.x

Tavakol, M. \& Dennick, R., 2011, 'Making sense of Cronbach's alpha', Internationa Journal of Medical Education 2, 53-55. https://doi.org/10.5116/ijme.4dfb.8dfd

Turney, P.B., 1996, Activity based costing: The performance breakthrough, Kogan Publishing company, CLA, London.

Veeira, R. \& Hoskin, K., 2004, 'Management accounting change in the financial services sector: The implementation of activity based costing in a Portuguese Bank', in Fourth Asia Pacific Interdisciplinary Research in Accounting Conference, July 4-6, Singapore, pp. 10-21.

Voss, K.E., Stem, D.E. \& Fotopoulos, S., 2000, 'A comment on the relationship between coefficient alpha and scale characteristics', Marketing Letters 11(2), 177-191. https://doi.org/10.1023/A:1008146924781

Wahab, B.A.B., Mohamad, M.H.S. \& Said, J.M., 2018, 'The implementation of activity based costing in the Accountant's Department of Malaysia', Asian Journa of Accounting and Governance 9, 75-89. https://doi.org/10.17576/AJAG-2018of Accoun

Xu, L., 2012, 'Implementation of activity based costing in China: A case study of a Chinese Multinational Company', Master's dissertation, University of Wollongong. 